\title{
Famílias brasileiras: um olhar sobre a diversidade a partir de dados de pesquisas domiciliares nacionais
}

\author{
Maria Coleta F. A. de Oliveira (PQ), Beatriz Z. Mojica (IC)
}

\section{Resumo}

Neste trabalho, a proposta central é realizar uma breve análise e discussão do arranjo domiciliar constituído por casais do mesmo sexo, a partir de informações presentes no Censo Demográfico 2010 e de teorias das Ciências Sociais e da Demografia que investigam o processo de transformação dos núcleos familiares.

Casais homossexuais, arranjos familiares, Demografia da família.

\section{Introdução}

Neste ano, a aprovação do casamento gay nos Estados Unidos mobilizou milhares de pessoas no mundo todo através de redes sociais, reacendendo o debate sobre o tema.

$\mathrm{O}$ presente projeto, que dá continuidade à pesquisa PIBIC/CNPq anterior, tem como objetivo principal tecer algumas considerações a respeito dos arranjos familiares brasileiros constituídos por casais do mesmo sexo, a partir da exploração dos dados do Censo Demográfico 2010 e de revisão bibliográfica da literatura das Ciências Sociais, da Demografia e do Direito.

\section{Resultados e Discussão}

Previamente à resolução do Conselho Nacional de Justiça (Resolução no 175/2013) que legalizou a união homoafetiva no Brasil, já em 2010, o Censo Demográfico traz informações acerca dos arranjos familiares formados por casais do mesmo sexo. Através do desmembramento da categoria "cônjuge" em "cônjuge de sexo diferente" e "cônjuge de mesmo sexo" na variável "relação com o responsável pelo domicílio", foi possível mensurar, pela primeira vez em uma pesquisa domiciliar nacional, a presença deste arranjo. Baseado nos dados provenientes desta investigação e com auxílio do pacote estatístico SPSS, foram realizadas algumas análises, a fim de compreender o perfil destes casais.

Em comparação aos responsáveis por domicílios constituídos por casais de sexo diferente, os de mesmo sexo apresentam escolaridade mais elevada (ensino médio completo a superior completo), mas equiparam-se quanto à faixa etária do responsável (entre 30 e 59 anos). Quanto à relação entre sexo e presença de filhos no domicílio, nota-se que a grande maioria dos casais de mesmo sexo com filhos é do sexo feminino, como ilustram os gráficos a seguir:

Gráfico 1: "Distribuição do arranjo 'casais do mesmo sexo sem filhos' por grandes regiões brasileiras

2010"

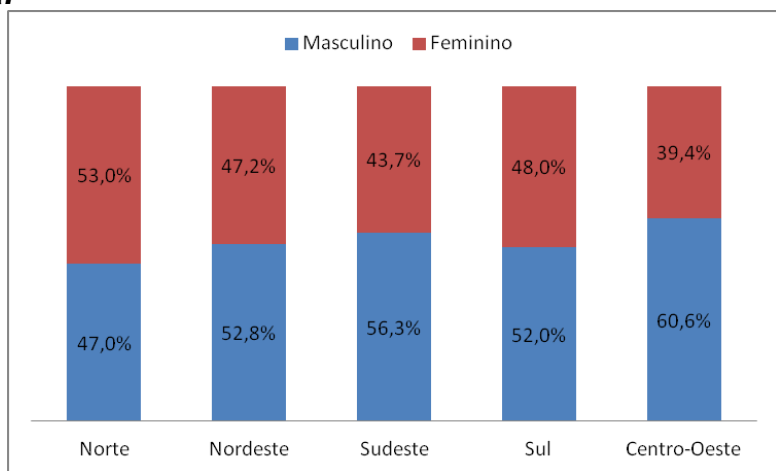

Gráfico 2: "Distribuição do arranjo 'casais do mesmo sexo com filhos' por grandes regiões brasileiras 2010"

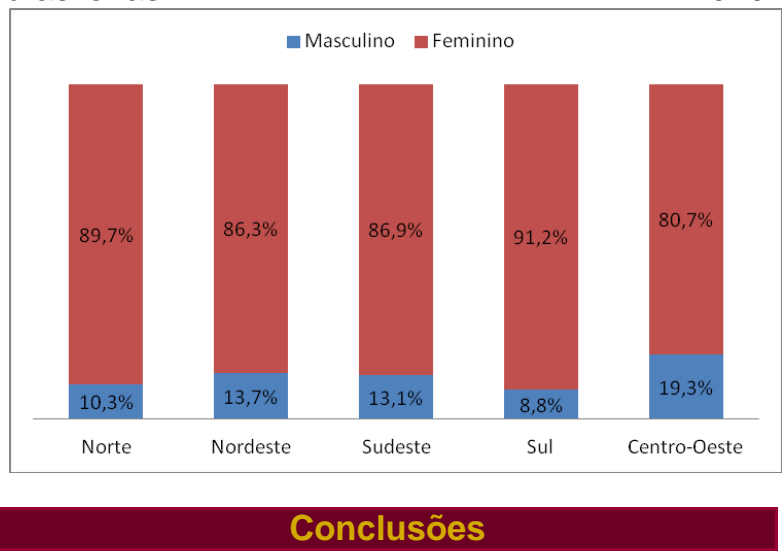

O reconhecimento legal dos arranjos familiares formados por casais homoafetivos é parte de um processo mais amplo de mudanças sociais. Apesar do Censo 2010 anteceder a Resolução no 175 , ele representa uma vitória para o movimento GLBT e constitui um marco na produção de informações sobre estes casais no Brasil.

\section{Agradecimentos}

Agradeço ao PIBIC/CNPq, pela bolsa de estudos concedida, à equipe coordenada por minha orientadora e ao NEPO/Unicamp pelos ensinamentos e pela estrutura fornecida.

\footnotetext{
Fundação SEADE. Boletim SP Demográfico. Abril 2015.

${ }^{2}$ IBGE. Censo Demográfico 2010.
} 